\title{
多成分系原水の全成分合計量の吸着等温線の 無次元化モデル
}

\section{湯浅 晶*}

IAST-Freundlich モデルを用いて多成分系吸着のシミュレーションを行い，全成分 合計量の吸着平衡特性におよぼす初期濃度, 活性炭添加量, 濃度残存率の影響について 検討した. 回分吸着等温線とカラム吸着等温線の差異と相互関係を明かにした上で, 初 期濃度と基準吸着量により無次元化した吸着等温線がほぼ成立することを示し，原水初 期濃度の変化による回分吸着等温線の変化を予測するための実用的なモデルを誘導し た.

Key Words : adsorption, multicomponent, equilibria, overall isotherm, IAST

\section{1.はじめに}

水中に溶存する種々の有機物の除去のために用いられ る活性炭吸着処理の効果を予測する上で，有機物の吸着 平衡特性の検討は欠かすことができない. 吸着等温線(平 衡濃度亡平衡吸着量の関係) を求めるには一般に次のよ うな試験方法が用いられる。

(1)有機物の初期濃度を一定として, 活性炭添加量を変え て回分吸着試験を行う。

(2)活性炭添加量を一定として, 有機物の初期濃度を変え て回分吸着試験を行う.

(3)カラムに一定量の活性炭を充填し, 有機物の流入濃度 を変えて通水して，カラム吸着試験を行う.

単成分系水溶液の場合には，(1)～(3)のどの試験方法に よっても得られる吸着等温線は同じであり, 成分と吸着 剤の組合せに応じて吸着等温線が定まるという普遍性が ある、それゆえ，個々の有機物の単成分系吸着等温線は その成分の吸着性の強弱を明確に示すものであり, 粒内 拡散係数などの吸着速度特性とならんで吸着処理の効果 を支配する重要な要素である。したがって，単成分系吸 着等温線を比較することにより，様々な有機化合物の吸 着性を評価したり，あるいは活性炭の銘柄による吸着能 力の差を評価することができる，このように意義の大き い吸着等温線を広い濃度範囲で精度よく測定するため に, (1)と(2)の方法を組み合わせて, 様々な初期濃度の有 機物水溶液に対して, 様々な活性炭添加量を設定して回 分吸着試験を行うことが多い。

組成未知の実際の用水や廃水の場合には, COD（化 学的酸素要求量) や TOC (全有機炭素量) などを指標 とする有機物全体量の吸着処理性を評価するために，(1) の試験法により吸着等温線を求めるのが一般的である.

* 正会員 工博 岐阜大学流域環境研究センタ一教授 （ ₹501-11 岐皋市柳戸 1 番 1 )
また，その結果得られた吸着等温線を用いて，多成分系 原水を擬似的な単成分とみなした種々の解析を行うこと も多い。しかし，多成分系水溶液の場合には，(1)（3)の 各試験方法によって得られる吸着等温線はそれぞれ異 なったものとなり，原水之活性炭の組合せにより 1 本の 吸着等温線が定まるという普遍性はない1). したがって, 多成分系原水中の有機物群を擬似的な単成分とみなすこ とは原理的に正しくない.

また，起源や濃度の異なる様々な原水に対する吸着等 温線を測定して原水中の有機物群の吸着性を比較評価す るにあたっては，原水初期濃度の違いを考慮して吸着等 温線の補正を行うなど，比較の前提条件を調整すること に十分な注意を払わなければならない。そのためには， (1)〜 (3)の各試験方法により得られる吸着等温線の意味を 明確にし，これらの吸着等温線の相互の関係を明らかに することが必要である.

本研究では，組成を仮定した多成分系原水の吸着平衡 について, IAST-Freundlich モデルに基づくシミュレ ーションを行い, 全成分合計量についての回分吸着等温 線と力ラム吸着等温線の関係を明らかにする。また，回 分吸着等温線におよぼす原水初期濃度の影響の規則性を 明らかにすることにより，原水初期濃度に応じて回分吸 着等温線を補正するための実用的なモデルを誘導するこ とを目的としている.

\section{IAST-Freundlich モデル}

Prausnitz 等 ${ }^{2), 3}$ は, 吸着相を理想溶液とみなして, 吸 着相における各成分の活量がその成分の吸着量分率に比 例するという仮定を Gibbs の吸着式に適用し, 次に示 すような多成分系の吸着平衡の式を導いた，等温下での 多成分系吸着においてある吸着平衡に達して界面拡張圧 が $\pi$ となり, 成分 $i$ の液相濃度と吸着量が各々 $C_{i}$ と $q_{i}$ になったとする．各成分の単成分系吸着平衡によって， 
Table 1 Composition of the model mixture-A and Freundlich constants of components.

\begin{tabular}{|r|c|l|l|l|l|l|l|}
\hline$i$ & $K_{i}$ & $1 / n_{i}$ & $\frac{C_{i 0}}{C_{t_{0}}}$ & $i$ & $K_{i}$ & $1 / n_{i}$ & $\frac{C_{i 0}}{C_{t_{0}}}$ \\
\hline 1 & 10 & 0.4 & 0.025 & 21 & 400 & 0.4 & 0.025 \\
2 & 20 & 0.3 & 0.025 & 22 & 400 & 0.2 & 0.025 \\
3 & 30 & 0.2 & 0.025 & 23 & 500 & 0.3 & 0.025 \\
4 & 40 & 0.5 & 0.025 & 24 & 500 & 0.4 & 0.025 \\
5 & 50 & 0.3 & 0.025 & 25 & 600 & 0.2 & 0.025 \\
6 & 60 & 0.4 & 0.025 & 26 & 600 & 0.5 & 0.025 \\
7 & 70 & 0.3 & 0.025 & 27 & 700 & 0.3 & 0.025 \\
8 & 80 & 0.2 & 0.025 & 28 & 700 & 0.4 & 0.025 \\
9 & 90 & 0.5 & 0.025 & 29 & 800 & 0.2 & 0.025 \\
10 & 100 & 0.3 & 0.025 & 30 & 800 & 0.4 & 0.025 \\
11 & 100 & 0.4 & 0.025 & 31 & 900 & 0.3 & 0.025 \\
12 & 100 & 0.5 & 0.025 & 32 & 900 & 0.4 & 0.025 \\
13 & 120 & 0.4 & 0.025 & 33 & 1000 & 0.3 & 0.025 \\
14 & 120 & 0.2 & 0.025 & 34 & 1000 & 0.5 & 0.025 \\
15 & 150 & 0.3 & 0.025 & 35 & 1200 & 0.4 & 0.025 \\
16 & 150 & 0.5 & 0.025 & 36 & 1200 & 0.2 & 0.025 \\
17 & 200 & 0.3 & 0.025 & 37 & 1500 & 0.3 & 0.025 \\
18 & 200 & 0.4 & 0.025 & 38 & 1500 & 0.5 & 0.025 \\
19 & 300 & 0.2 & 0.025 & 39 & 2000 & 0.3 & 0.025 \\
20 & 300 & 0.5 & 0.025 & 40 & 2000 & 0.4 & 0.025 \\
\hline
\end{tabular}

$\mathrm{K}(\mathrm{mmol} / \mathrm{kg}), \mathrm{C}\left(\mathrm{mmol} / \mathrm{m}^{3}\right)$

これと同じ界面拡張圧 $\pi$ となるときの液相濃度と吸着 量の值を各々 $C_{i}^{*}$ 亡 $q_{i}^{*}$ とすると, 次式が成立する.

$$
C_{i}=\frac{q_{i}}{\sum_{j=1}^{N} q_{j}} C_{i}^{*} \quad(i=1,2, \cdots, N)
$$

$\sum_{j=1}^{N} \frac{q_{j}}{q_{j}^{*}}=$

$$
\pi A / R T=\int_{0}^{C_{i}^{*}} \frac{q_{i}^{*}}{C_{i}^{*}} d C_{i}^{*}
$$

ただし， $q_{i}^{*}$ と $C_{i}^{*}$ の関係は単成分系吸着等温線であら わされる。これらは理想吸着相溶液理論 (Ideal Adsorbed Solution Theory（IAST）と呼ばれ, 多成分系における 吸着平衡特性の解明に広く応用されている(1) 12).

Crittenden 等 ${ }^{11), 12)}$ は, 単成分系の吸着等温線が次の Freundlich 式

$$
q_{i}^{*}=K_{i}\left(C_{i}^{*}\right)^{1 / n_{i}} \quad(i=1,2, \cdots, N)
$$

となる場合をIAST に適用して, 次式を誘導した。

$$
\begin{aligned}
& C_{i}=\frac{q_{i}}{q_{t}}\left[\frac{\pi A / R T}{n_{i} K_{i}}\right]^{n i} \ldots \ldots \ldots . . . \\
& \pi A / R T=n_{i} q_{i}^{*}=\sum_{j=1}^{N}\left(n_{j} q_{j}\right) \\
& q_{t}=\sum_{j=1}^{N} q_{j} \ldots \ldots \ldots \ldots \ldots \ldots \ldots
\end{aligned}
$$

回分式吸着の場合には, 活性炭量 $M$, 液相体積 $V$, 初期濃度 $C_{i 0}$ 亡すると, 各成分の濃度 $C_{i}$ 亡吸着量 $q_{i}$ の 関係は次の物質収支式

$$
q_{i}=\left(C_{i 0}-C_{i}\right) V / M \quad(M \neq 0) \cdots
$$

で与えられるので, これに式（5）のIAST-Freundlich モデルを代入すると次式となる.

$$
C_{i 0}-\frac{M}{V} q_{i}-\frac{q_{i}}{\sum_{j=1}^{N} q_{j}}\left[\frac{\sum_{j=1}^{N}\left(n_{j} q_{j}\right)}{n_{i} K_{i}}\right]_{n i}=0
$$

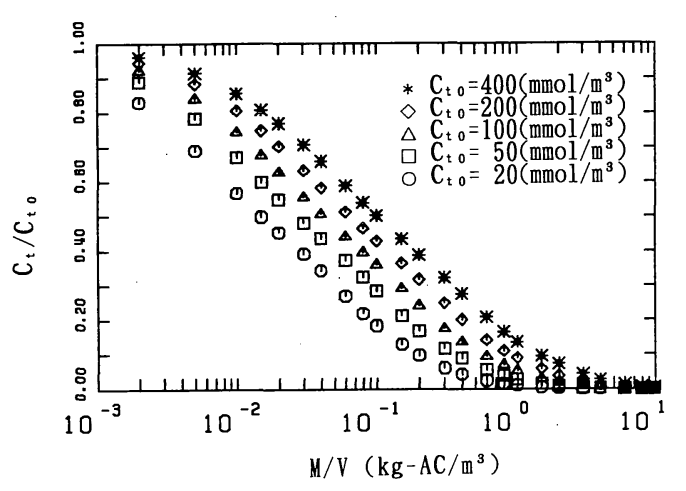

Fig.1 Relation between activated carbon dose and overall removal of Mixture-A.

各成分の単成分系での吸着等温線 (Freundlich 式の 係数 $K_{i}$ 亡指数 $\left.1 / n_{i}\right)$ が既知であれば, 各成分の初期濃 度が $C_{i 0}$ で全成分合計の初期濃度 $C_{t 0}\left(=\sum C_{i 0}\right)$ の多成 分系原水に対して, 活性炭添加濃度 $M / V$ で吸着処理を 行った場合の最終平衡時の各成分の吸着量 $q_{i}$ は, 式 $(9)$ の $N$ 元連立非線形方程式 ( $N$ は成分数) を解くことに より得られる. 本研究では, 式 (9) を Newton-Raphson 法により線形近似した連立方程式を $L U$ 分解法によ り解いて各成分の平衡吸着量 $q_{i}$ を求め, さらに式 (5) より各成分の平衡濃度 $C_{i}$ を計算して, 全成分合計の平 衡濃度 $C_{t}\left(=\sum C_{i}\right)$ と平衡吸着量 $q_{t}\left(=\sum q_{i}\right)$ の関係を 全成分合計量の回分吸着等温線としてプロットした.

なお, 式（9）において $M / V=0$ とした場合は, 式（5) において $C_{i}=C_{i 0}$ とした場合と同じであり, 解としてカ ラム吸着における平衡 (完全破過) 時の吸着量 $q_{i 0}$ を得 る. この場合の合計濃度 $C_{t 0}$ はカラム流入原水の合計濃 度であり, 合計吸着量 $q_{t 0}\left(=\sum q_{i 0}\right)$ 亡流入濃度 $C_{t 0}$ の関 係を全成分合計量のカラム吸着等温線としてプロットし た.

\section{3. 模擬原水に対するシミュレーション}

\section{（1）模擬原水の組成の設定}

吸着性の異なる様々な成分の組成 (モル分率の分布) を仮定した原水（Model mixture-A）をTable 1 のよう に設定した. 各成分の単成分系吸着等温線の $K_{i}$ の值は, $C_{i}=1\left(\mathrm{mmol} / \mathrm{m}^{3}\right)$ における吸着量を示しており, 多く の有機化合物にみられるような $10 〜 2000(\mathrm{mmol} / \mathrm{kg})$ の範囲 ${ }^{13)}$ で設定した. また， $1 / n_{i}$ の值は $0.2 \sim 0.5$ の範 囲に設定した. 各成分の $1 / n_{i}$ が異なるので, 濃度によっ て各成分の吸着性の順序は変わってくるが, おおむね成 分番号 $i$ が大きくなるにつれて吸着性が高くなるように 設定している.

原水の初期濃度 $C_{t 0}$ が $20,50,100,200,400\left(\mathrm{mmol} / \mathrm{m}^{3}\right)$ の各々の場合について, 活性炭添加濃度 $M / V$ を 10 
(a) $\mathrm{C}_{\mathrm{t} 0}=400\left(\mathrm{mmol} / \mathrm{m}^{3}\right)$

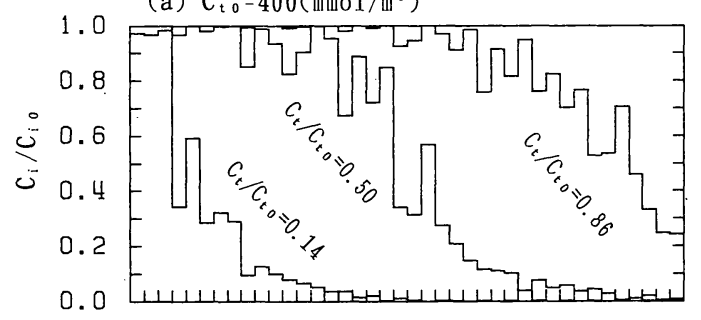

(b) $\mathrm{C}_{\mathrm{t} 0}=100\left(\mathrm{mmol} / \mathrm{m}^{3}\right)$

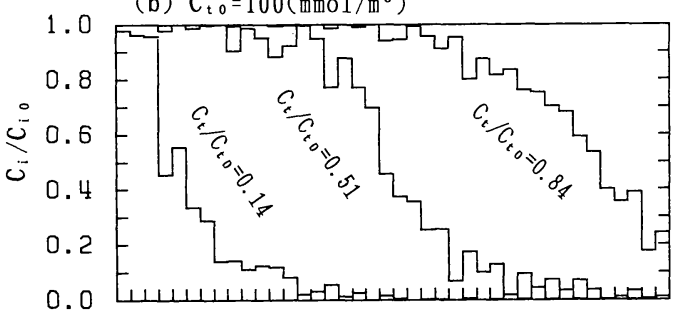

(c) $\mathrm{C}_{\mathrm{t} 0}=20\left(\mathrm{mmol} / \mathrm{m}^{3}\right)$

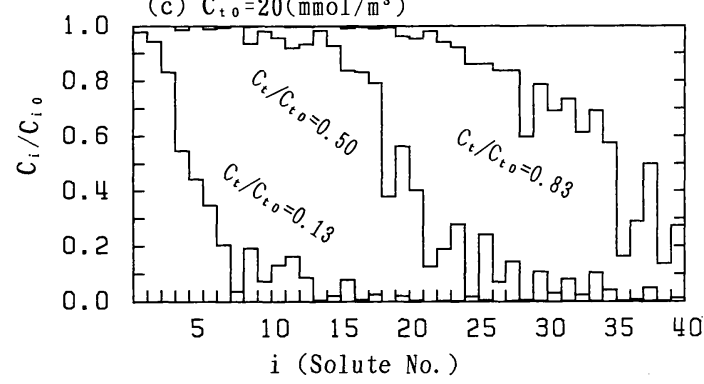

Fig.2 Residual distribution of components.

$\left(\mathrm{kg} / \mathrm{m}^{3}\right)$ の範囲に設定して回分吸着平衡のシミュレー ションを行い, 全成分合計量でみた吸着平衡特性につい て検討した。計算結果をFig. 1 に示す. 原水初期濃度が 高いほど，一定の除去率に達するのにも，また，一定の 処理水濃度まで低下させるのにも, 活性炭添加量が多く 必要であることが示される. 液相の残存成分の分布を Fig.2 に示す. 全成分合計の液相残存率 $C_{t} / C_{t 0}$ が大き い場合には, 吸着性の強い成分が卓越して吸着され, 吸 着性の弱い成分はほとんど吸着されずに残留している. 全残存率 $C_{t} / C_{t 0}$ が同じであれば, 原水初期濃度が異なっ ていても液相残存成分の分布はほぼ同じ形状を示してい る. 分布形が細部で異なってくるのは濃度レベルによっ て各成分の吸着性の順序が若干変動するからであるが, 細部の微小な変動を除いたおおまかな残存成分分布はほ ぼ同じである.したがって, 原水初期濃度が異なってい ても, 吸着平衡時の液相の組成（残存成分のモル分率の 分布）は全残存率 $C_{t} / C_{t 0}$ に応じてほぼ定まってくると みなすことができる.

\section{(2) 吸着等温線についての考察}

Table 1 で成分組成を設定した原水についてのシミュ レーション結果から, 平衡濃度と平衡吸着量の関係を

Fig.3 と Fig.4 に示す. Fig.3 に示した同一記号のプロッ

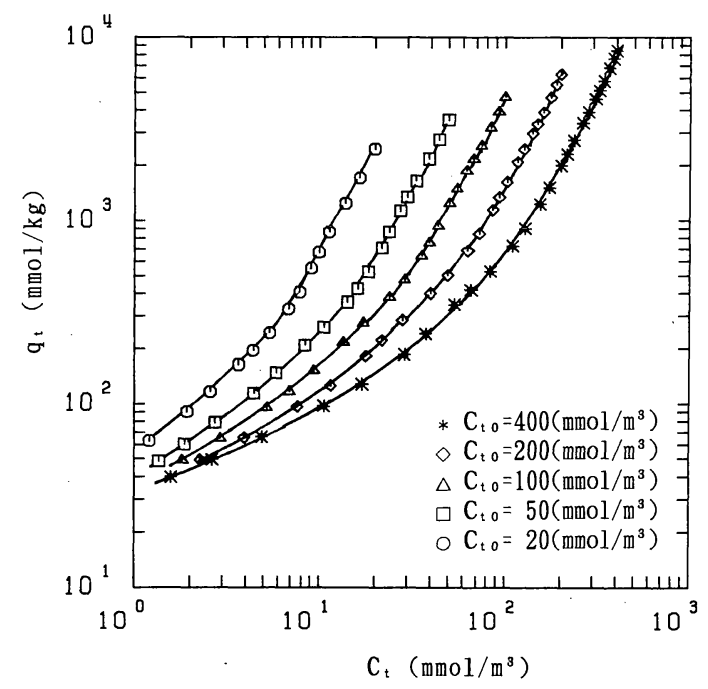

Fig.3 Batch adsorption isotherm of Mixture-A for fixed initial concentration. [Eq.(10)]

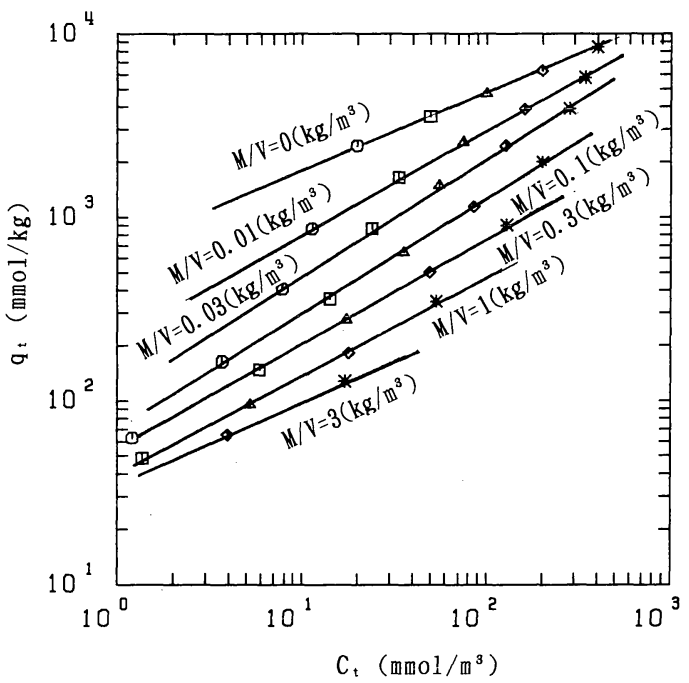

Fig.4 Batch adsorption isotherm for fixed dose of activated carbon. [Eqs.(11)(12)]

卜を結んだ各々の等温線は，1.の(1)の試験方法（初期 濃度一定の条件)で得られる回分吸着等温線をあらわす。 また，Fig.4に示した各々の等温線は，1.の(2)の試験方 法 (活性炭添加量一定の条件) で得られる回分吸着等温 線をあらわす。

Fig.3に示すように(1)のタイプの回分吸着等温線は初 期濃度によって異なり，また，Fig.4に示すように(2)の タイプの回分吸着等温線も活性炭添加量によって異な り, 単成分系吸着等温線のような濃度に応じて一義的に 平衡吸着量が定まるという特徴を持たない。この理由は, 多成分系の場合には吸着処理後の液相の残留成分の組成 が原水の成分組成とは異なったものとなり, 液相濃度の みならず液相の組成に応じて平衡吸着量が定まってくる 


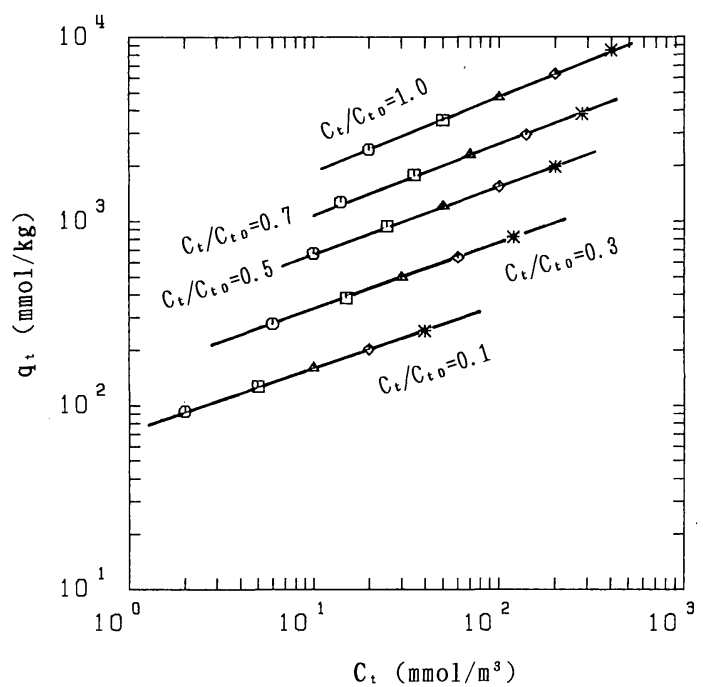

Fig.5 Batch adsorption isotherm for fixed overall residual ratio. [Eq.(13)]

ためである．多成分系の場合には，Fig.2 に示したよう に吸着性の強い成分から順々に除去されていくので, 全 成分合計量の残存率 $C_{t} / C_{t 0}$ が小さくなるにつれて液相 には吸着性の弱い成分群しか残留しないようになる。そ れゆえ，Fig.3に示されるように平衡濃度 $C_{t}$ が同じで あっても, 残存率 $C_{t} / C_{t 0}$ が小さくなるにつれて，ある いは原水初期濃度 $C_{t 0}$ が高いほど吸着量 $q_{t}$ は減少する.

Fig.3 と Fig.4 に示した(1)と(2)のタイプの回分吸着等 温線は, いずれも試験条件（原水初期濃度あるいは活性 炭添加量）をパラメーターとして平衡濃度と平衡吸着量 の関係を点綴したものである.また，Fig.4の中で活性 炭添加量 $M / V=0$ の場合の等温線は実際には回分吸着 試験で得ることは不可能であるが，この場合の吸着量は カラム吸着試験における流入濃度 $C_{t 0}$ に対する平衡吸着 量 $q_{t 0}$ をあわしており，1.の(3)のイプのカラム吸着 等温線をあらわす。これらの吸着等温線は次式であらわ される。

(1)のタイプ; $q_{t}=$ func $_{1}\left(C_{t}, C_{t 0}\right) \cdots$

(2)のタイプ; $q_{t}=\operatorname{func}_{2}\left(C_{t}, M / V\right)$

(3)のタイプ; $q_{t 0}=$ func $_{3}\left(C_{t 0}\right)$

液相濃度と液相組成に応じて平衡吸着量が定まり，ま た, 液相組成は全成分合計量の残存率 $C_{t} / C_{t 0}$ にほぼ支 配されることを考えると，次式のように残存率 $C_{t} / C_{t 0}$ をパラメーターとして平衡濃度と平衡吸着量の関係をあ らわす方が吸着等温線として合理的であると考えられ る.

$q_{t}=$ func $_{4}\left(C_{t}, C_{t} / C_{t 0}\right)$

このような残存率 $C_{t} / C_{t 0}$ をパラメーターとする吸着 等温線はいずれも Fig.5 に示すように Freundlich 型と
Table 2 Freundlich constants of the overall adsorption isotherms in Fig.5.

\begin{tabular}{|c|c|c|}
\hline$C_{t} / C_{t o}$ & $1 / \mathrm{n}_{\mathrm{t}}$ & $\mathrm{K}_{\mathrm{t}}$ \\
\hline $\begin{array}{l}0.1 \\
0.2 \\
0.3 \\
0.4 \\
0.5 \\
0.6 \\
0.7 \\
0.8 \\
0.9 \\
1.0\end{array}$ & $\begin{array}{l}0.34 \\
0.35 \\
0.36 \\
0.37 \\
0.36 \\
0.36 \\
0.37 \\
0.38 \\
0.39 \\
0.41\end{array}$ & $\begin{array}{r}74 \\
111 \\
145 \\
197 \\
295 \\
394 \\
484 \\
562 \\
641 \\
705\end{array}$ \\
\hline average & 0.37 & \\
\hline
\end{tabular}

なり，各々の吸着等温線の $1 / n_{t}$ の値は Table 2 に示す ようにわずかな差異はあるもののほぼ一定とみなすこと ができ, $K_{t}$ の值のみが残存率 $C_{t} / C_{t 0}$ の関数となる.

$$
\begin{aligned}
& q_{t}=K_{t} C_{t}^{1 / n t} \ldots \ldots \ldots \ldots \\
& K_{t}=\text { func }_{5}\left(C_{t} / C_{t 0}\right) \\
& n_{t}=\text { constant } \cdots \cdots \cdots
\end{aligned}
$$

式 (15) において $C_{t} / C_{t 0}=1$ の場合はカラム吸着平衡 に相当するので, 式 (12) のカラム吸着等温線は次式で あらわされる。

$$
\begin{aligned}
& q_{t 0}=\text { func }_{3}\left(C_{t 0}\right)=K_{t 0} C_{t 0}^{1 / n t} \\
& K_{t 0}=\text { func }_{5}(1) \cdots \cdots \ldots \ldots \ldots \ldots
\end{aligned}
$$

（3）基準吸着量による回分吸着等温線の無次元化

Fig.3 で示した原水初期濃度をパラメーターとする回 分吸着等温線の形状は互いによく似ている. また,

Fig.5 に示した残存率 $C_{t} / C_{t 0}$ をパラメーターとする吸 着等温線にも, $1 / n_{t}$ の値の共通性が認められた. そこで, 濃度亡吸着量について次のように無次元化し, 回分吸着 等温線の無次元化をはかった。

初期濃度 $C_{t 0}$ に対する平衡吸着量 $q_{t 0}$ を基準として吸 着量を無次元化すると, 式 $(14) \sim(18)$ より,

$$
\begin{aligned}
\frac{q_{t}}{q_{t 0}} & =\frac{\text { func }_{5}\left(C_{t} / C_{t 0}\right)}{\text { func }_{5}(1)}\left(C_{t} / C_{t 0}\right)^{1 / n t} \\
& =\text { func }_{6}\left(C_{t} / C_{t 0}\right) \ldots \ldots \ldots \ldots \ldots \ldots \ldots
\end{aligned}
$$

func $_{6}(1)=1$

となり, 無次元化吸着量 $q_{t} / q_{t 0}$ は無次元化濃度 (残存率) $C_{t} / C_{t 0}$ の関数となることが期待される.

Fig.3 と Fig.4に示した平衡濃度と平衡吸着量の関係 を無次元化してプロットした結果を Fig.6に示す. 無次 元化回分吸着等温線のプロットはほぼ 1 本の曲線に収束 し，式（19）が近似的に成立することが明らかである. このことは，成分の組成比が同じ原水であれば，原水の 初期濃度が変わっても func $6\left(C_{t} / C_{t 0}\right)$ の関数形はほと んど変わらないことを示す。式 (19) と式 (17) より,

$$
q_{t}=\text { func }_{3}\left(C_{t 0}\right) \cdot \text { func }_{6}\left(C_{t} / C_{t 0}\right)
$$

となる.したがって, 多成分系の回分吸着平衡における 全吸着量 $q_{t}$ は, 液相組成比一定の条件において濃度が 


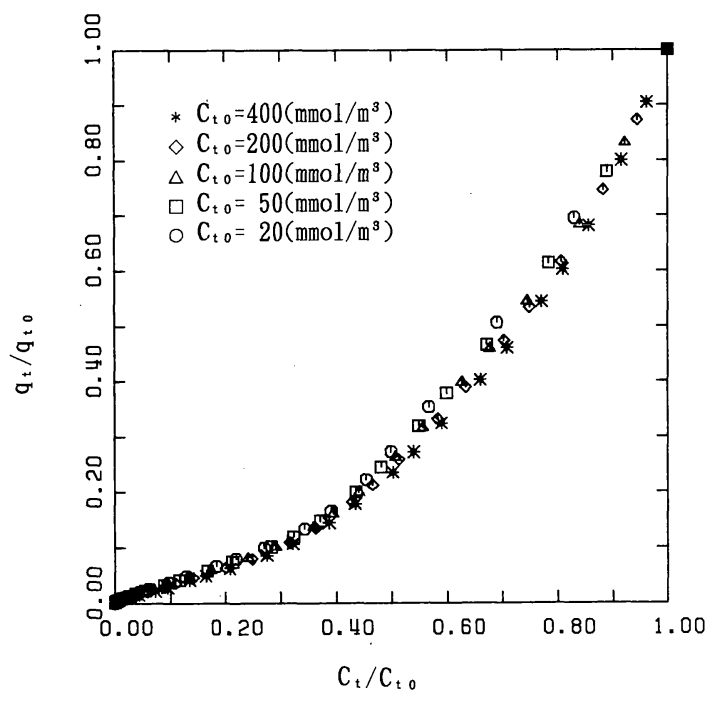

Fig.6 Dimensionless batch isotherm. [Eq.(19)]

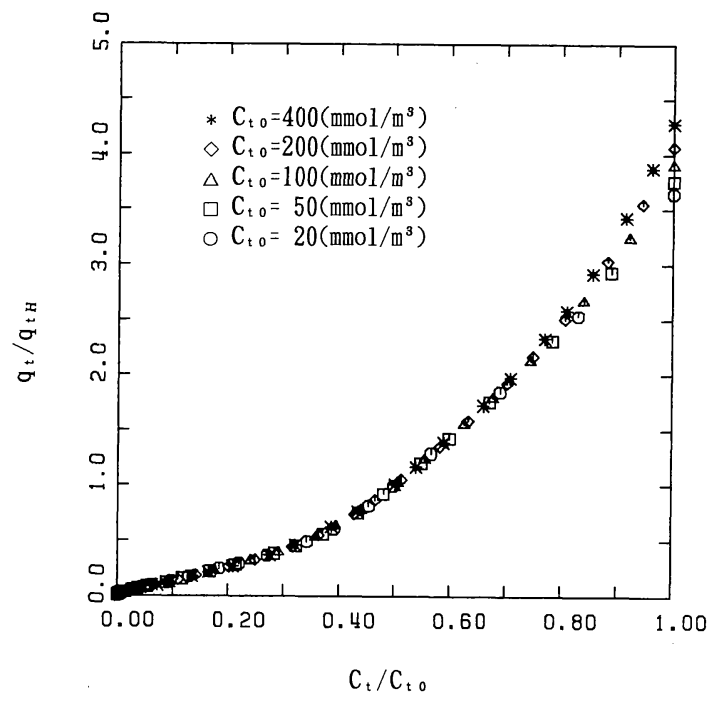

Fig.7 Dimensionless batch isotherm. [Eq.(23)]
吸着量に及ぼす影響をあらわす項 $\mathrm{func}_{3}\left(C_{t 0}\right)$ と, 吸着 による液相残留成分の組成の変化が吸着量の減少に及ほ す影響をあらわす項 func $_{6}\left(C_{t} / C_{t 0}\right)$, の二つに支配され ることが明らかである。

初期濃度 $C_{t 0}$ に対する平衡吸着量 $q_{t 0}$ を基準吸着量と するかわりに，ある一定の残存率 $C_{t} / C_{t 0}$ に対する吸着 量を基準として無次元化する方法を用いることもでき る. 例えば, $C_{t} / C_{t 0}=1 / 2$ に対する吸着量（即ち, 回分 吸着により全成分合計の濃度が半減したときの吸着量) $q_{t H}$ を基準吸着量とすると, 式 (14) と式 (15) より,

$$
\begin{aligned}
& q_{t H}=K_{t H}\left(C_{t 0} / 2\right)^{1 / n t} \\
& K_{t H}=\text { func }_{5}(1 / 2) \cdots
\end{aligned}
$$

となる.したがって, 無次元化吸着量 $q_{t} / q_{t H}$ は次式の ようにあらわされる。

$$
\begin{aligned}
\frac{q_{t}}{q_{t H}} & =\frac{\operatorname{func}_{5}\left(C_{t} / C_{t 0}\right)}{\text { func }_{5}(1 / 2) \cdot(1 / 2)^{1 / n t}}\left(C_{t} / C_{t 0}\right)^{1 / n t} \\
& =\text { func }_{7}\left(C_{t} / C_{t 0}\right) \ldots \ldots \ldots \ldots \ldots \ldots \ldots \ldots \ldots
\end{aligned}
$$

func $_{7}(1 / 2)=1$

このような無次元化による回分吸着等温線のプロット

も Fig.7に示すようにほぼ1 本の曲線に収束し, 式 (19) 之同様に式 (23) も近似的に成立することが明らかであ る.

Fig.6 と Fig.7における若干のばらつきと収束性の違 いは, Table 2 に示した $1 / n_{t}$ の值のわずかな差異に起因 しており， $C_{t} / C_{t 0}$ が 0.8 以下の範囲での収束性は Fig.7 のほうがよいものの, $C_{t} / C_{t 0}=1$ で若干のばらつきが生 じる.しかし，Fig.6 と Fig.7 のいずれの場合でも吸着 量のばらつきは約 $\pm 5 \%$ 以内にすぎず，実用的にはいず れの場合も許容誤差範囲内にあるとみなしうる.ただし,
すでに述べたように，初期濃度 $C_{t 0}$ に対する平衡吸着量 $q_{t 0}$ は回分吸着試験では測定できない。原理的にはカラ 么吸着試験によって $q_{t 0}$ を測定しうるものの，実際には 破過曲線が著しいテーリングを示す場合が多く，破過曲 線の積分計算によって $q_{t 0}$ を精度よく測定することは一 般に困難である。したがって， $q_{t 0}$ を基準吸着量とする よりも，Fig.7のような $q_{t H}$ を基準吸着量とする無次元 化回分吸着等温線の方が実用性が高い.

\section{（4）初期濃度による回分吸着等温線の補正}

$q_{t 0}$ や $q_{t H}$ を基準吸着量亡する無次元化回分吸着等温 線が成立する場合には, 初期濃度を用いて回分吸着等温 線を次のように補正することができる.

式 (19) と式 (17) (18) より,

$q_{t}=$ func $_{5}(1) \cdot C_{t 0}^{1 / n t} \cdot$ func $_{6}\left(C_{t} / C_{t 0}\right)$

となる。また式 (24) と式（19）（21）より，

$q_{t}=$ func $_{5}(1 / 2) \cdot\left(C_{t 0} / 2\right)^{1 / n_{t}} \cdot$ func $_{7}\left(C_{t} / C_{t 0}\right)$

となる.したがって，次式を得る.

$$
\begin{aligned}
\frac{q_{t}}{C_{t 0}^{1 / n_{t}}} & =\text { func }_{5}(1) \cdot \operatorname{func}_{6}\left(C_{t} / C_{t 0}\right) \\
& =(1 / 2)^{1 / n t} \cdot \text { func }_{5}(1 / 2) \cdot \text { func }_{7}\left(C_{t} / C_{t 0}\right) \\
& =\text { func }_{8}\left(C_{t} / C_{t 0}\right) \cdots \ldots \ldots \ldots \ldots \ldots \ldots \ldots \ldots \ldots \ldots \ldots \ldots \ldots \ldots \ldots \ldots \ldots \ldots \ldots \ldots
\end{aligned}
$$

すなわち, ある濃度残留率に対する平衡吸着量は原水初 期濃度の $1 / n_{t}$ 乗に比例して増加することを式 (26) は 示しており, Fig.3における(1)のタイプの回分吸着等温 線におよぼす初期濃度の影響の規則性をあらわしてい る.この方法による補正回分吸着等温線のプロットは, Fig.8に示すようにほぼ 1 本の曲線に収束し, 式 (26) が近似的に成立することが明らかである。 


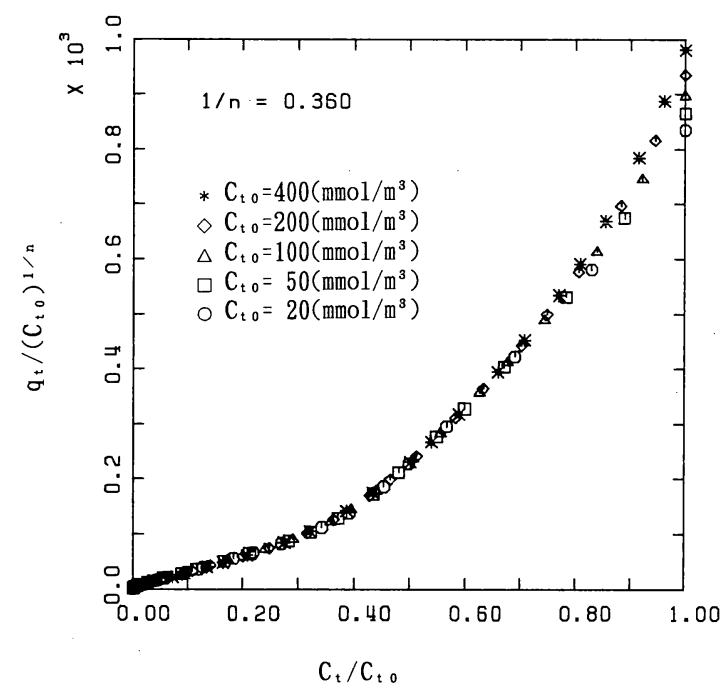

Fig.8 Modified batch isotherm. [Eq.(26)]

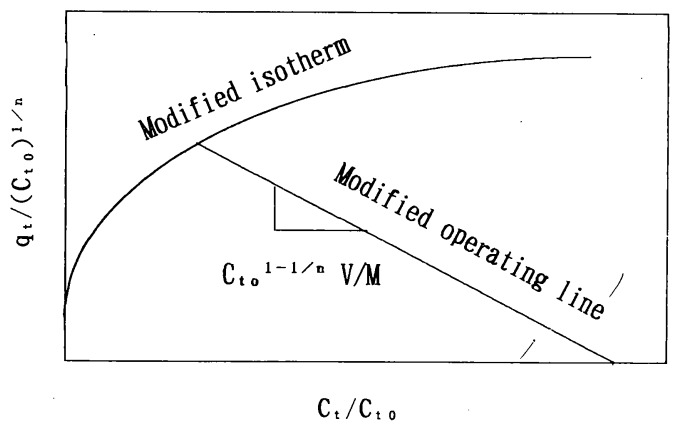

Fig.9 Modified batch operating line. [Eq.(27)]

\section{（5）回分吸着操作線の補正}

式（8）で示した物質収支式（回分吸着操作線）上吸 着等温線の交点は吸着平衡点を示すので, 回分吸着処理 効率の予測のために多用される．この操作線を Fig.9 に 示すように式 (26) の補正回分吸着等温線と同じグラフ 上に描くためには，次式のような補正操作線の式に変換 すればよい。

$$
\frac{q_{t}}{C_{t 0}^{1 / n}}=\left[1-\frac{C_{t}}{C_{t 0}}\right] \frac{V}{M} C_{t 0}^{1-1 / n t}
$$

補正操作線（直線）の傾きの逆数は, ある一定の吸着 処理効率 (残存率 $C_{t} / C_{t 0}$ ) に達するのに必要な活性炭 添加量パラメーターとなる. 即ち, Fig.1 に示した活性 炭添加濃度と残存率の関係におよぼす初期濃度の影響を 排除するには, 活性炭添加量パラメーター $\left[C_{t 0}^{1 / n_{t}-1} M / V\right]$ と残存率の関係としてあらわせばよく, Fig.10に示す ように次の式が成立する.

$$
C_{t} / C_{t 0}=\text { func }_{9}\left(C_{t 0}^{1 / n t-1} M / V\right)
$$

したがって，式（29）あるいはFig.11に示すように， ある一定の除去率を得るのに必要な活性炭添加量は初期

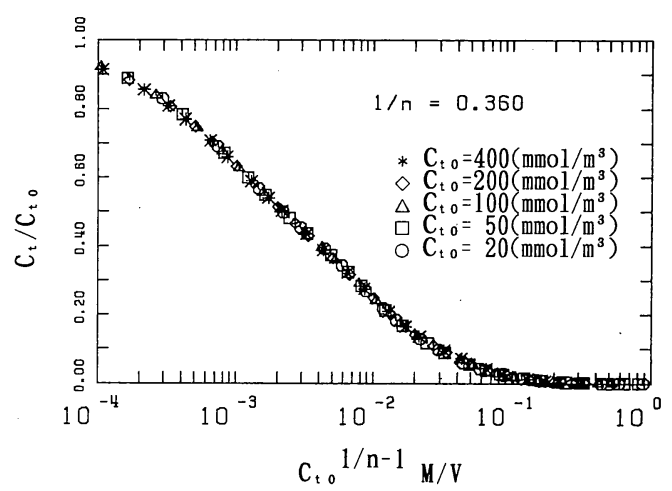

Fig.10 Relation between activated carbon dose parameter and overall removal. [Eq.(28)]

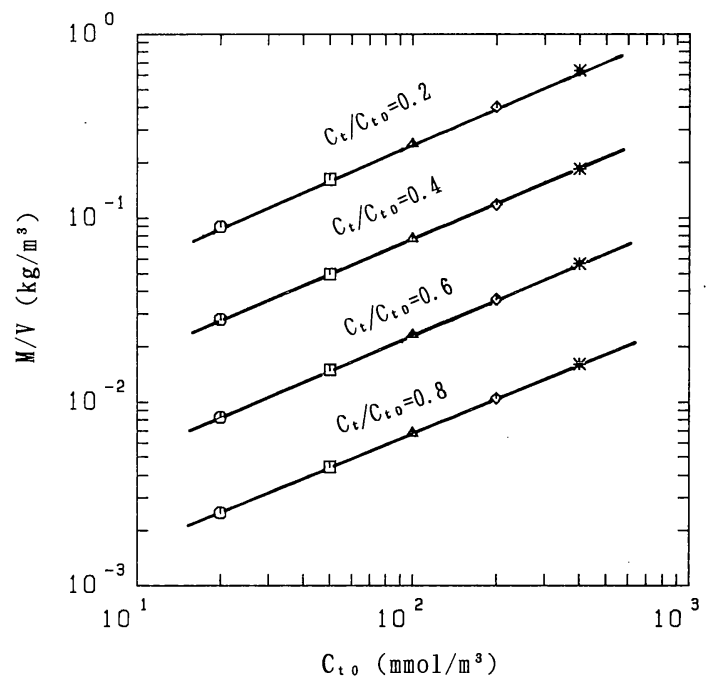

Fig.11 Influence of initial overall concentration on activated carbon demand. [Eq.(29)]

濃度の $1-1 / n_{t}$ 乗に比例して増加する。

$$
M / V=C_{t 0}^{1-1 / n t} \cdot \text { func }_{10}\left(C_{t} / C_{t 0}\right)
$$

(6) $1 / n_{t}$ の意義

式 (19) や式 (23) の無次元化回分吸着等温線之式 (26) の補正回分吸着等温線がそれぞれ近似的に成立し，それ にしたがって式（28）（29）が導かれたことの最大の要 因は，Fig.5 に示した残存率 $C_{t} / C_{t 0}$ をパラメーターと する Freundlich 型の吸着等温線のべき指数 $1 / n_{t}$ が残存 率にかかわらずほぼ一定値であるとみなすことができた ことにある. 単成分系の吸着等温線の $1 / n_{i}$ は吸着量の 濃度依存性をあらわすための各成分個別の指数であるの に対して, 多成分系原水の $1 / n_{t}$ は原水を構成する成分 群全体としての吸着特性をあらわすものである.

原水の成分組成 $C_{i 0}$ がざの上うな分布形であっても, 構成成分の $1 / n_{i}$ が同一值の場合には成分群全体を代表 する $1 / n_{t}$ も同じ值となり, 式 (14) 〜式 (26) に示され たことがらが理論的に成立する ${ }^{14)}$. しかし Table 1 に示 
Table 3 Composition of Mixture-B

\begin{tabular}{|r|r|r|l|l|l|l|l|}
\hline $\mathrm{i}$ & \multicolumn{1}{|c|}{$\mathrm{K}_{\mathrm{i}}$} & $1 / \mathrm{n}_{\mathrm{i}}$ & $\frac{\mathrm{C}_{\mathrm{i} 0}}{\mathrm{C}_{\mathrm{t} 0}}$ & $\mathrm{i}$ & $\mathrm{K}_{\mathrm{i}}$ & $1 / \mathrm{n}_{\mathrm{i}}$ & $\frac{\mathrm{C}_{\mathrm{i} 0}}{\mathrm{C}_{\mathrm{t} 0}}$ \\
\hline 1 & 5 & 0.5 & 0.05 & 11 & 150 & 0.5 & 0.05 \\
2 & 10 & 0.3 & 0.05 & 12 & 200 & 0.4 & 0.05 \\
3 & 15 & 0.5 & 0.05 & 13 & 300 & 0.2 & 0.05 \\
4 & 20 & 0.4 & 0.05 & 14 & 400 & 0.4 & 0.05 \\
5 & 30 & 0.2 & 0.05 & 15 & 500 & 0.3 & 0.05 \\
6 & 40 & 0.4 & 0.05 & 16 & 600 & 0.2 & 0.05 \\
7 & 50 & 0.3 & 0.05 & 17 & 800 & 0.4 & 0.05 \\
8 & 60 & 0.2 & 0.05 & 18 & 1000 & 0.3 & 0.05 \\
9 & 80 & 0.4 & 0.05 & 19 & 1500 & 0.5 & 0.05 \\
10 & 100 & 0.3 & 0.05 & 20 & 2000 & 0.3 & 0.05 \\
\hline
\end{tabular}

Table 4 Composition of Mixture-C

\begin{tabular}{|r|r|l|l|l|l|l|l|}
\hline $\mathrm{i}$ & $\mathrm{K}_{\mathrm{i}}$ & $1 / \mathrm{n}_{\mathrm{i}}$ & $\frac{\mathrm{C}_{\mathrm{i}}}{\mathrm{C}_{\mathrm{t}}}$ & $\mathrm{i}$ & $\mathrm{K}_{\mathrm{i}}$ & $1 / \mathrm{n}_{\mathrm{i}}$ & $\frac{\mathrm{C}_{\mathrm{i} 0}}{\mathrm{C}_{\mathrm{t} 0}}$ \\
\hline 1 & 10 & 0.40 & 0.01 & 11 & 300 & 0.50 & 0.09 \\
2 & 20 & 0.30 & 0.02 & 12 & 350 & 0.30 & 0.10 \\
3 & 50 & 0.50 & 0.05 & 13 & 400 & 0.40 & 0.08 \\
4 & 70 & 0.45 & 0.05 & 14 & 450 & 0.20 & 0.06 \\
5 & 100 & 0.35 & 0.06 & 15 & 500 & 0.35 & 0.03 \\
6 & 120 & 0.20 & 0.03 & 16 & 600 & 0.30 & 0.02 \\
7 & 150 & 0.30 & 0.04 & 17 & 700 & 0.40 & 0.04 \\
8 & 200 & 0.35 & 0.06 & 18 & 800 & 0.25 & 0.05 \\
9 & 220 & 0.40 & 0.07 & 19 & 900 & 0.45 & 0.03 \\
10 & 250 & 0.25 & 0.08 & 20 & 1000 & 0.35 & 0.03 \\
\hline
\end{tabular}

したような $1 / n_{i}$ の值が異なる成分からなる多成分系原 水の場合でも成分群全体を代表する特性值 $1 / n_{t}$ が存在 することは， $1 / n_{i}$ を一定値 $\left(1 / n_{t}\right)$ とする別の仮想成分 の組成を設定することによりほぼ同等な吸着平衡特性 (全成分合計量であらわした回分吸着等温線) を再現し うる可能性を示唆している．また，このような解析法を 用いて, 組成が未知の実際の原水中の有機物群を仮想成 分であらわそうとする場合には，原水中の有機物群を代 表する特性值 $1 / n_{t}$ を求めることが第一に必要となる.

\section{4. モデルの検証と実用性}

無次元化回分吸着等温線や補正回分吸着等温線への収 束あるいは回分吸着等温線に対する初期濃度の影響の規 則性が，Table 1 に定義した模擬原水だけでなく様々な 組成の原水についても成り立てば，式（14）－式（29） に示されたことがらは多成分系原水の吸着平衡特性に関 する有用な一つのモデルとなる，そこで，様々な成分組 成を仮定した原水について回分吸着平衡のシミュレー ションを行い，モデルの一般性について検証した. これ らのモデルの根幹は式（19）（21）（26）が近似的に成立 するか否かにあり，この中のいずれかが近似的に成立す れば他の式も近似的に成立することが明らかであり，こ こでは式（19）について検証する.

検証に用いた模擬原水の組成を Table 3〜Table 5 に 示す. シミュレーション結果を Fig.12〜Fig.14に示す. 組成の違いによって回分吸着等温線の形状は様々であ る. しかし，いずれの模擬原水の場合にも無次元化回分 吸着等温線のプロットはほぼ 1 本の曲線に収束し, 式
Table 5 Composition of Mixture-D

\begin{tabular}{|r|r|l|l|r|r|r|l|}
\hline $\mathrm{i}$ & \multicolumn{1}{|c|}{$\mathrm{K}_{\mathrm{i}}$} & $1 / \mathrm{n}_{\mathrm{i}}$ & $\frac{\mathrm{C}_{\mathrm{i} 0}}{\mathrm{C}_{\mathrm{t} 0}}$ & $\mathrm{i}$ & $\mathrm{K}_{\mathrm{i}}$ & $1 / \mathrm{n}_{\mathrm{i}}$ & $\frac{\mathrm{C}_{\mathrm{i} 0}}{\mathrm{C}_{\mathrm{t} 0}}$ \\
\hline 1 & 20 & 0.35 & 0.1 & 6 & 500 & 0.35 & 0.1 \\
2 & 50 & 0.50 & 0.1 & 7 & 800 & 0.40 & 0.1 \\
3 & 80 & 0.30 & 0.1 & 8 & 1000 & 0.30 & 0.1 \\
4 & 100 & 0.20 & 0.1 & 9 & 1500 & 0.45 & 0.1 \\
5 & 200 & 0.40 & 0.1 & 10 & 2000 & 0.25 & 0.1 \\
\hline
\end{tabular}

$\mathrm{K}(\mathrm{mmol} / \mathrm{kg}), \mathrm{C}\left(\mathrm{mmol} / \mathrm{m}^{3}\right)$

(19）がおおむね成立することが明らかである.

多成分系原水の全成分合計量の吸着平衡特性に関する これらのモデルは, 実際の用水や廃水の回分吸着平衡試 験により得られる吸着等温線のデータから原水中の有機 物群の吸着性を解析するための基礎となる. 例えば，種 類の異なる原水の吸着性を比較するためには，同じレべ ルの初期濃度に対する回分吸着等温線に基づいて比較す ることが必要である. 原水とその希釈試料水について回 分吸着試験を行って, 無次元化回分吸着等温線や補正回 分吸着等温線への収束性を確認しておけば, 任意の初期 濃度に対する回分吸着等温線をモデルにより予測するこ とが可能となる.

また，ある用水や廃水の吸着等温線の季節的変動の データに基づいて, 水中有機物群の吸着性の変化を追跡 するのに応用することができる，例えば，回分吸着によ り初期濃度の半分まで除去されたときの吸着量 $q_{t H}$ (濃 度半減時吸着量）を有機物群全体の平均的な吸着性の指 標としたり，初期濃度の $25 \%$ が除去されたときの吸着 量を強吸着性成分群の吸着性の指標とみなすものとす る. 季節的な原水濃度の変動の影響を排除した上でこれ らの吸着性の変化を追跡するためには，ある決められた 初期濃度（標準初期濃度）に対する回分吸着等温線に変 換した上でこのような指標吸着量を算出して比較するこ とが必要となる。

また，粒状活性炭固定層での吸着破過曲線は，活性炭 粒子径 ·通水速度 - 固定層全長などの操作条件や，原水 中の有機物の吸着平衡特性や粒子内拡散速度特性，およ び原水濃度などの様々な因子に支配されるが，原水中の 全有機化合物の組成を完全に把握すること自体がほとん ビ不可能であり，厳密な理論に基づくシミュレーション を行って破過曲線を予測するのは非常に困難である．し かし，近年になって，組成が未知の実際の原水を用いて 少量の小粒径活性炭を充填したミニカラムによる短時間 の通水実験の結果から, 吸着平衡特性や粒子内拡散係数 などの算定を必要とせずに, 固定層吸着過程の相似律に 基づいて実規模装置での破過曲線を予測する実用的な方 法 ${ }^{15)}{ }^{16)}$ が提案されている.このようなスケールアップあ るいはスケールダウンの手法と本研究で提案したモデル を組み合わせると, 固定層吸着での平衡吸着量（飽和吸 着量）に及ぼす流入濃度の影響が本モデルにより予測し 

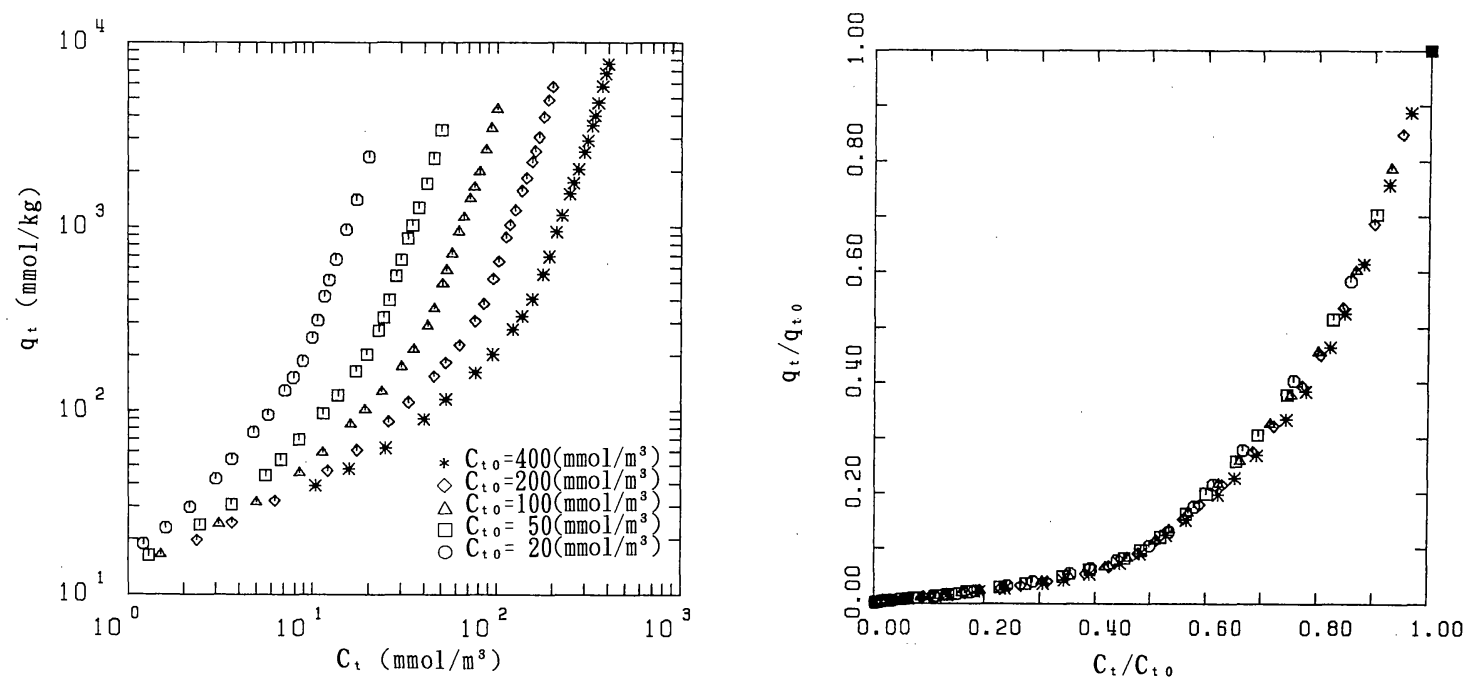

Fig.12 Batch adsorption isotherm of Mixture-B
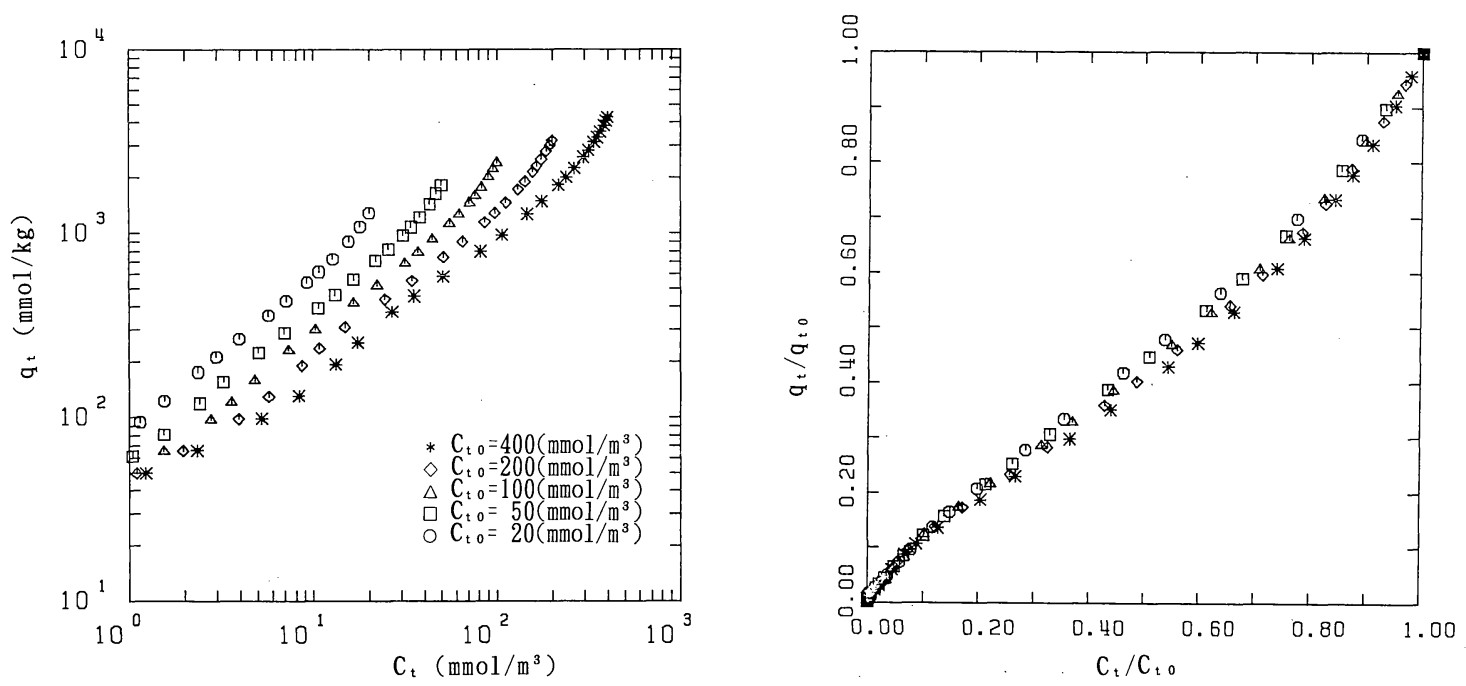

Fig.13 Batch adsorption isotherm of Mixture-C
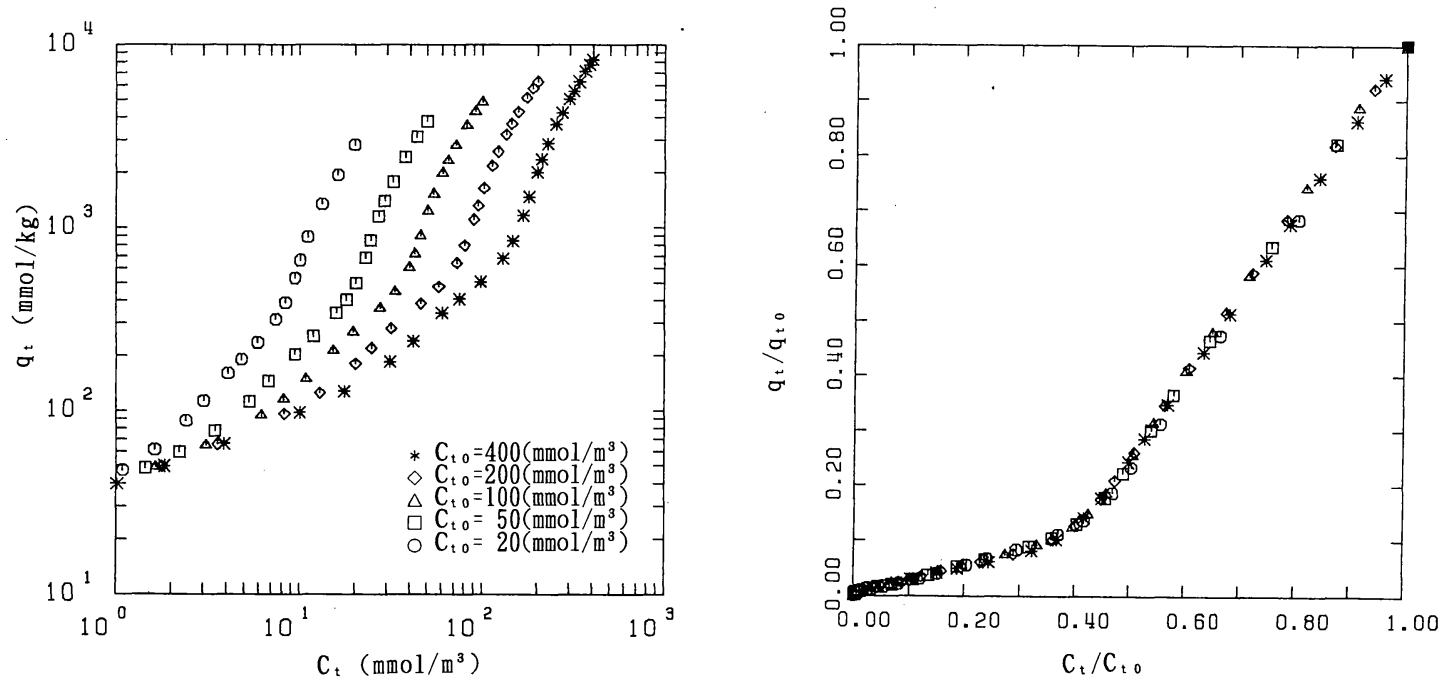

Fig.14 Batch adsorption isotherm of Mixture-D 
うるので, ある一つの原水濃度に対する固定層吸着試験 の破過曲線のデー夕に基づいて，流入濃度が異なる（た だし，原水中の有機物群の組成の比率は同じとする）場 合の破過曲線を予測したり活性炭の寿命を予測すること が可能となる.

\section{5.おわりに}

本研究では, IAST-Freundlich モデルに基づくシミュ レーション結果に基づき, 多成分系原水の回分吸着等温 線におよぼす初期濃度の影響を明らかにし, 多成分系原 水の全成分合計量の吸着平衡特性をあらわす次のモデル を誘導した。

（1）各成分の単成分系吸着等温線が Freundlich 式 で与えられるような成分からなる多成分系原水の場合に は, 各成分の Freundlich 指数 $1 / n_{i}$ の值が異なっていて も, 全成分合計量についてのカラム吸着等温線および残 存率をパラメーターとする回分吸着等温線は, 式 (14) と式（17）に示すように，いずれもFreundlich 式であ らわすことができる.これらの等温線の $1 / n_{t}$ は共通の 一定值であり， $K_{t}$ のみが残存率の関数亡なる.

（2）基準吸着量により無次元化した吸着量を用いる と, 式 (19) あるいは式 (21) に示すような無次元化回 分吸着等温線が成立する.すなわち, 多成分系原水の回 分吸着平衡関係を一本の無次元化回分吸着等温線として あらわすことができる。

（3）一定の残存率に対する吸着量は初期濃度の $1 / n_{t}$ 乗に比例して増加し, 式 (26) の補正回分吸着等 温線が成立する. したがって, 回分吸着平衡によりある 一定の除去率を達成するのに必要な活性炭添加量は, 式

（28）（29）に示すように, 初期濃度の $1-1 / n_{t}$ 乗に比 例して増加する.

IAST は熱力学的に誘導された理論であり，したがっ て本研究で誘導された上記のモデルにおいて濃度や吸着 量はモル基準であらわしている，実際には組成が未知の 用水や廃水中の有機物群をモ儿濃度であらわすことは不 可能であり，一般には TOC などの代替指標濃度でしか 測定できない. したがって，本研究で得られたモデルが 指標濃度であらわした吸着等温線についても近似的に成 立するかについて，さらに検討が必要であろう.

なお, 本研究におけるシミュレーションは岐阜大学情 報処理センターの F A COM M-760/6 を利用して行っ た。

\section{記号}
$A$ : 活性炭の比表面積 $\left(\mathrm{m}^{2} / \mathrm{kg}\right)$
$C_{i}$ : 成分 $i$ の液相平衡濃度 $\left(\mathrm{mol} / \mathrm{m}^{3}\right)$
$C_{i 0}$ : 成分 $i$ の原水初期濃度 $\left(\mathrm{mol} / \mathrm{m}^{3}\right)$
$C_{i}^{*}$ : 成分 $i$ の単成分系での液相平衡濃度 $\left(\mathrm{mol} / \mathrm{m}^{3}\right)$

$C_{t}$ : 全成分合計の液相平衡濃度 $\left(\mathrm{mol} / \mathrm{m}^{3}\right)$

$C_{t 0}$ : 全成分合計の原水初期濃度 $\left(\mathrm{mol} / \mathrm{m}^{3}\right)$

$K_{i}$ : 成分 $i$ の単成分系 Freundlich 係数 $(\mathrm{mol} / \mathrm{kg})$

$K_{t}$ : 成分群全体の Freundlich 係数 $(\mathrm{mol} / \mathrm{kg})$

$K_{t H}$ : 全成分合計濃度半減時の成分群全体の Freundlich 係数 $(\mathrm{mol} / \mathrm{kg})$

$K_{t 0}$ : 原水の成分群全体の Freundlich 係数 $(\mathrm{mol} / \mathrm{kg})$

$M$ : 活性炭量 $(\mathrm{kg})$

$n_{i}$ : 成分 $i$ の単成分系 Freundlich 指数

$n_{t}$ : 成分群全体の Freundlich 指数

$q_{i}$ : 成分 $i$ の平衡吸着量 $(\mathrm{mol} / \mathrm{kg})$

$q_{i 0}$ : 原水初期組成に対する成分 $i$ の平衡吸着量

$(\mathrm{mol} / \mathrm{kg})$

$q_{i}^{*}$ : 成分 $i$ の単成分系での平衡吸着量 $(\mathrm{mol} / \mathrm{kg})$

$q_{t}$ : 全成分合計の平衡吸着量 $(\mathrm{mol} / \mathrm{kg})$

$q_{t H}$ : 全成分合計濃度半減時の全成分合計の平衡吸着 量 $(\mathrm{mol} / \mathrm{kg})$

$q_{t 0}$ : 原水初期組成に対する全成分合計の平衡吸着量 $(\mathrm{mol} / \mathrm{kg})$

$R:$ 気体定数 $\left(\mathrm{J} / \mathrm{mol} /{ }^{\circ} \mathrm{K}\right)$

$T:$ 絶対温度 $\left({ }^{\circ} \mathrm{K}\right)$

$V:$ 液相の体積 $\left(\mathrm{m}^{3}\right)$

$\pi$ : 界面拡張圧 $(\mathrm{N} / \mathrm{m})$

\section{参 考 文 献}

1) Fettig, J. \& Sontheimer, H. : Kinetics of adsorption on carbon-III. Natural organic material, Journal of Envioronmental Engineering, Vol.113, No.4, pp.780 794, 1987.

2) Myers, A.L. \& Prausnitz, J.M. : Thermodynamics of mixed-gas adsorption, A.I.Ch.E.Journal, Vol.11, No.1, pp.121 $\sim 127,1965$.

3) Radke, C.J. \& Prausnitz, J.M. : Thermodynamics of multi-solute adsorption from dilute liquid solutions, A.I.Ch.E.Journal, Vol.18, No.4, pp.761 768, 1972.

4) Jossens, L. \& Prausnitz, J.M. et.al. : Thermodynamics of multi-solute adsorption from dilute aqueous solutions, Chemical Engineering Science, Vol.33, pp.1097 1106, 1978.

5) Singer, P. C. \& Yen, C. : Adsorption of alkyl phenols by activated carbon, Activated Carbon Adsorption of Organics from the Aqueous Phase, Vol.1 (Edited by Suffet, I.M. \& McGuire, M.J.), pp.167 189, Ann Arbor Science, 1980.

6) Fritz, W. et.al. : Competitive adsorption of dissolved organics on activated carbon, ibid., pp.193 211, Ann Arbor Science, 1980.

7) DiGiano, F. A. et.al. : Simplifying the description of competitive adsorption for practical application in water treatment, ibid., pp.213 228, Ann Arbor Science, 1980.

8) Fritz, W. \& Schlunder, E.U. : Competitive adsorption of dissolved organics onto activated carbon-I. Adsorption equilibria, Chemical Engineering Science, Vol.36, pp.721 $\sim 730,1981$. 
9) Yen, C. \& Singer, P. C. : Competitive adsorption of phenols on activated carbon, Journal of Envioronmental Engineering, Vol.110, No.5, pp.976 989, 1984.

10) Fettig, J. \& Sontheimer, H. : Kinetics of adsorption on carbon-II. Multisolute systems, ibid., Vol.113, No.4, pp.780 794, 1987.

11) Crittenden, J. C. et.al. : Prediction of multicomponent adsorption equilibria using ideal adsorbed solution theory, Envioronmental Science and Technology, Vol.19, No.11, pp.1037 1043, 1985.

12) Crittenden, J.C. et.al. : Prediction of multicomponent adsorption equilibria in backgroud mixtures of unknown composition, Water Research, Vol.19, No.12, pp.1537 1548, 1985.

13) Dobbs, R.A. and Cohen, J.M. : Carbon adsorption isotherms for toxic organics, Municipal Environmental Research Laboratory, Office of Research and Development, U.S. Environmental Protection Agency, EPA600/8-80-023, 1980.

14）湯浅 晶：多成分系原水の吸着等温線におよぼす原水中 の成分の吸着強度分布の影響, 土木学会論文集第 II 部門 投稿予定.

15) Crittenden, J. C. et.al. : Design of rapid small-scale adsorption tests for a constant diffusivity, Journal WPCF, Vol.58, No.4, pp.312 319, 1986.

16）松井佳彦, 他：マイクロカラム法による固定層吸着過程 の迅速評価, 水道協会雑誌, Vol. 61, No. 4, pp. 13 22, 1992.

(1992.9.7 受付)

\section{MODELING THE DIMENSIONLESS OVERALL ADSORPTION ISOTHERM OF A MULTICOMPONENT MIXTURE}

Akira YUASA

Simulation of multicomponent adsorption equilibria based on IAST-Freundlich model was executed for the evaluation of the overall isotherms which represent the behavior of the sum of all components. Batch adsorption isotherm was found to differ quite regularly with the change of the initial overall concentration. Batch isotherms plotted for the fixed overall removal rate and the column isotherm were described by Freundlich equations and the value of Freundlich exponent $1 / \mathrm{n}$ was essentially identical for all these isotherms. From these findings, two dimensionless overall isotherm models and a modified isotherm model were derived to compensate the difference of the initial overall concentration. 